\title{
CLINICAL AND LABORATORY PORTRAIT OF PATIENTS WITH ORAL NEOPLASM
}

\author{
Asya Krasteva \\ Department of Imaging and Oral Diagnostic, \\ Faculty of Dental Medicine, Medical University of Sofia, Bulgaria
}

\begin{abstract}
:
The aim of this study was to present the clinicallaboratory picture of patients with oral carcinomas compared to healthy subjects.

The alterations of oral and dental status, the level of salivary proteins and the abuse of main oral carcinogens (alcohol and nicotine) were studied.
\end{abstract} protein

Key words: oral carcinoma, dental status, salivary

Clinical and laboratory portrait of untreated patients with oral neoplasm

- average age - 56 years

- mean age - 56 years (40-77)

- men: women - approximately 25:10

- $62 \%$ smokers

- average nicotine consumption in the group - 14 cigarettes daily

- taking hard alcohol more than a half of patients$500 \mathrm{ml}$ )

- $60 \%$ associated abuse - alcohol and cigarette

Oral status

- $8 \%$ - only without extracted teeth

- 54\% - without caries

- $69 \%$ - missing teeth obturation

- Fully restored occlusal defects only in two out of twenty three patients

- Patients with moderate and severe gingivitis (mean PBI - 3,33)

- Bad oral hygiene, consisting of:

o Average DI - 2,09 (compared to 0.79 in controls) o Average CI - 1,25 (.25 compared with controls)

o Average OHI - 3,35 (compared to 1.04 in controls)

The patients' oral health status is characterized with poor dental status, unsolved prosthetic problems and neglected oral hygiene. Besides, the used restorative materials are cheap.

- Significant correlation between:

o DI,CI and the number of missing teeth

o The degree of inflammation of periodontal tissues and the number of extracted teeth and with CI

Modified immune status of patients, reflected in changed levels of studied salivary proteins :

o Increased levels of individual proteins are expressed at higher levels of total protein in saliva $(\mathrm{x}=3,9$ $\mathrm{g} / 1$ to $1,3 \mathrm{~g} / 1$ in controls)

o Higher levels of $\operatorname{IgA}(\mathrm{x}=151 \mathrm{mg} / 1$ to $84 \mathrm{mg} / 1$ in controls)

o Higher levels of $\operatorname{IgG}(\mathrm{x}=87 \mathrm{mg} / 1$ to $25 \mathrm{mg} / 1$ in controls)

o Higher levels of CRP ( $\mathrm{x}=0,346 \mathrm{mg} / 1$ to 0,105 $\mathrm{mg} / \mathrm{l}$ in controls)

o Higher levels of haptoglobin $(\mathrm{x}=45 \mathrm{th} \mathrm{mg} / 1$ to fifteen $\mathrm{mg} / \mathrm{l}$ at the controls)

- Depressed oral secretory immune system: a low secretory $\operatorname{IgA}$

- In treated cancer

increased $\operatorname{sg} \mathrm{A}$ and lower haptoglobin compared with untreated patients

Compared to the studied diseases (psoriasis, IBD, oral preneoplasm, treated oral cancer patients)

- elevated IgA, IgG, CRP and haptoglobin

Address for correspondence:

Assya Krasteva, DM

Department Imaging and oral diagnostic, Faculty of Dental medicine - Sofia

1, G. Sofiyski Str., 1000 Sofia, Bulgaria

e-mail: asyakrasteva@abv.bg 